\title{
Earnings management to achieve positive earnings surprises in case of medium size companies listed in Poland
}

\author{
Piotr Wójtowicz \\ Accounting Department, Faculty of Management, Cracow University of Economics ul. Rakowicka 27, 31-510 Cracow \\ E-mail: piotr.wojtowicz@uek.krakow.pl
}

\begin{abstract}
Earnings management in Polish listed companies was the subject of only several studies, mainly theoretical, but none of them is related to earnings management to meet analysts' expectations. The aim of the paper is to detect any signals of earnings management to achieve zero or small positive earnings surprises. The sample comprises 609 observations from years 2012-2014 related to medium size companies listed at Warsaw Stock Exchange. Distribution of scaled annual earnings surprise (difference between realized and forecasted earnings scaled by beginning total assets) is analyzed. It contains unusually high frequency of small positive surprises. If the module of earnings surprise is small it is more probable that the real value was higher than the forecast - meeting or beating the forecast, so small positive earnings surprises are more probable than negative. If the module of earnings surprise is high it is more probable that the forecast of income was higher than the real value - neither meeting nor beating the forecast. Results are not sensitive to the choice of earnings surprise metric.
\end{abstract}

Keywords: Analysts Forecasts; Earnings Management; Earnings Surprise; Emerging Economy; Warsaw Stock Exchange.

\section{Introduction}

Capital market participants, especially investors and analysts, focus their attention on realized earnings. Before the earnings announcements professional analysts formulate earnings forecasts. It is natural that realized earnings differ from forecasts but previously conducted research show that market is sensitive to the magnitude and direction of this difference, called commonly in literature "earnings surprise". Significant stock price declines are associated with even small negative earnings surprises (Skinner \& Sloan 2002, Kinney et al. 2002). Positive market responses to meeting or beating earnings forecasts are documented by many authors (Bartov et al. 2002, Kasznik \& McNichols 2002, Lopez \& Rees 2002, Rees \& Sivaramakrishnan 2007). Earnings management to achieve analysts' forecasts is documented in many recent papers (Degeorge et al. 1999, Burgstahler \& Eames 2003, Phillips et al. 2003, Phillips et al. 2004, Frank \& Rego 2006, Burgstahler $\&$ Eames 2006). Comprehensive review of the literature dealing with earnings management (hereafter EM) around earnings benchmarks, including analysts forecasts, present (Habib \& Hansen 2008). Callao et al. (2014b) present investigation of EM from chronological, methodological and cross-country perspective. The last perspective is developed in (Callao et al. 2014a), so they add to country analysis conducted previously by many other authors (Leuz et al. 2003, Burgstahler et al. 2006, Wójtowicz 2010). The country of origin influences the perceptions and the results of EM investigations (Callao et al. 2014b, p. 136).

The investigation in the field of EM began in the U.S. The reason for such a situation is obvious when we consider history and significance of capital market, mainly stock exchanges, in this country. Research on EM in Europe also has its history, but has been done mainly in Western Europe. Emerging economies, like Po land, are explored only in very limited extent or even unexplored at all. EM in Polish companies is the subject of only several studies, mainly theoretical, which are in short discussed in section two of the paper. Since none of them is related to EM to meet analysts' expectations the aim of the paper is to give a glimpse at the problem of EM to achieve zero or small positive earnings surprises. The analyzed sample consists of medium size - mWIG 40 - companies listed at Warsaw Stock Exchange (WSE). Consistent with previous research, it is shown that distribution of annual earnings surprises contain unusually high frequency of small positive surprises.

The remainder of this paper is organized as follows. The next section provides a brief discussion of EM and related world-wide and Polish literature and develops the research issues introduced here. Section 3 presents a description of data used in the empirical analysis and the specific problems related to data collection. Section 4 reports results. Final section concludes with a summary and suggestions for further research.

\section{Hypotheses development and related re- search}

Incentives for public companies to beat benchmarks are discussed by Habib \& Hansen (2008). They argue that evidence from accounting research is mixed, but generally shows that companies have capital market incentives to beat all three earnings benchmarks. Usually tested benchmarks are the value of earnings (loss avoidance), earnings improvement, i.e. smoothness (earnings changes), and the analyst forecast benchmark. CEOs have cash and equity-based compensation incentives to beat the earnings improvement and analyst forecast benchmark. Managers also ap- 
pear to "strategically" manage earnings to meet or just beat the analyst forecast benchmark prior to managerial stock sales. The cost of debt is affected by companies meeting or beating benchmarks. Auditors also recognize the importance of beating the analyst forecast benchmark for their clients.

Thresholds are important, in general, because market reacts positively to positive earnings news and hence managers are concerned about reporting an earnings number that meets or exceeds market expectations (Degeorge et al. 1999, p. 5-8). Failure to meet or beat market expectations results in adverse consequences for the company. Growth companies missing analysts' forecast by $0,5 \%$ of stock price suffer a significantly negative abnormal return of $-10 \%$ to $-15 \%$ (Skinner \& Sloan 2002, p. 299). Graham et al. (2005, pp. 24-29) discuss reasons for meeting benchmarks and report that failure to meet earnings benchmarks results first of all in an increase in the uncertainty about future prospects and a perception among outsiders that there are deep, previously unknown problems at the company. This leads to increased market scrutiny of the reported earnings number, increased possibility of lawsuits, additional time and effort required to justify failure (Graham et al 2005, pp. 29-32).

Earnings are used as a key performance indicator of business success and are on the top of the list of managerial goals. Graham et al. (2005, p. 5) indicate that CFOs believe that earnings, not cash flows, are the key metric considered by outsiders. The two main earnings benchmarks are quarterly earnings for the same quarter last year and the analyst consensus estimate (Graham et al. 2005, pp. 22-23). Executives believe that hitting earnings benchmarks builds credibility with the market and helps to maintain or increase their company's stock price. Investors need a simple benchmark to evaluate company's performance, which reduces the costs of information processing due to the availability of abundant information. Academic research is full of evidence documenting the primacy of accounting earnings in equity valuation, debt contracting, managerial compensation contracts and so forth as it is documented in the seminal paper by S. P. Kothari (2001). The importance attached to earnings, and the assumption that investors rely on simple heuristics suggest that reporting earnings that are positive, greater than last year, and greater than the consensus analyst forecast all have positive valuation implications. Given the significant potential benefits associated with meeting or beating earnings benchmarks, managers try to alter reported earnings or influencing analysts' expectations as it is documented by Burgstahler \& Eames (2006). Meeting benchmarks boosts managements' credibility in being able to meet stakeholder expectations and avoid costly litigation costs that could be triggered by unfavorable earnings surprises (Habib \& Hansen 2008, p. 9).

Traditionally, EM is seen as sneaky managers pulling the wool over the eyes of naive owners by manipulating accruals, but the owners, too, can benefit from EM (Arya et al. 1998). Arya et al. (2003) argue that managed earnings is not necessarily an evil rather, within limits it promotes efficient decisions. Moreover, EM is a useful device to communicate private information to owners because such practice reduces owner intervention (Arya et al 1998). This proposition is premised on the assumption of Revelation Principle. When the Revelation Principle holds the performance of any mechanism under which managers manipulate earnings can be replicated by a mechanism under which managers' report earnings truthfully (Arya et al. 1998, p. 7).

Arya et al. (1998) are not the only advocates of managers discretion and therefore of EM. Social norms put emphasis on personal and professional responsibility in accounting and business, on "fair representation", which is called by Sunder (2010, p. 111) a moral compass for accounting. Social norms give room for personal judgment and managers' discretionary decisions including activity called in the accounting literature "earnings management". However, the principal goal is to give useful information to stakeholders and to add to the process of value creation. Such information does not has to be prepared strictly in line with uniform written standards because in the extremely rare circumstances compliance with those standards would be misleading (compare par. 19-24 of IAS 1).

Results of the investigations presented in the literature show that EM in European emerging economies, like Poland, is explored in a very limited extent. Nevertheless, every-day experience, existing world-wide and Polish literature give the premise that EM to meet analysts' forecasts in Poland is still ongoing. Before we formulate research hypothesis we shall mention some important facts from Polish history which help to understand contemporary context of Polish economic situation and the role of capital market.

Variable political situation and military conflicts reduced the power of Poland in the $17^{\text {th }}$ century. Despite the process of reforms, including The Polish Constitution (the first to be written after the constitution of the US), Russia, Austria and Prussia together divided Poland up in three partitions: in 1773, 1793 and finally in 1795. Poland lost its independence for 123 years. The partition of Poland is meaningful for the development of economic situation of the nation, including future accounting system since the legislation of the invaders had great effect on the development of law and accounting in Poland. The war between napoleonian France and Russia resulted in the arrival of Napoleon to Warsaw (capital of the state before the partition). Napoleon created self-governing Grand Duchy of Warsaw in 1807, which was defeated in 1815 by the creation of Congress Kingdom of Poland with the Russian Tsar as a king. The Napoleonic Commercial Code was adopted in the Grand Duchy and later in the Congress Kingdom, and remained in force until 1934 in the Second Polish Republic. In the parts of Poland administrated by Germany and Austro-Hungary, the German Commercial Code was applied (Jaruga \& Bailey 1998, p. 1565).

Polish capital market traditions go back to 1817 , when the Warsaw Mercantile Exchange was established (New York Stock Exchange was founded in 1817 too), the predecessor of Warsaw Stock Exchange. The city of Warsaw was the part of Russia.

Independence was gained again with the end of World War I as in 1918 and Polish state was reestablished. The creation of Second Republic required the reintegration of the diverse business and accounting practice. The existence of Second Republic (19181939) was characterized by governmental interventionism in economic development, with emphasis on credit protection and tax collection. The accounting and auditing legislation was consolidated in Commercial Code (Kodeks Handlowy) 1934, which was influenced by the German Code. Accounting was generally regulated by this Code, although precedence was given to fiscal regulation. In practice there was an obligation to prepare two sets of financial statements: one for commercial and one for taxation purposes, the latter being a restatement of the former. The influence of Warsaw Stock Exchange was weak because the law level of private savings delayed the development of the market. The annual financial statements of listed companies were required to be audited and published (Jaruga \& Bailey 1998, p. 1566).

A 20-year period of social and political troubles were interrupted by the German $\left(1^{\text {st }}\right.$ of September, 1939) and the Soviet $\left(17^{\text {th }}\right.$ on September, 1939) invasion and the outbreak of World War II. Poland suffered terribly under the occupation called Fourth Partition of Poland (1939-1945). The German system of compulsory unified accounting was extended into the regions under German occupation, while the Soviet accounting system was introduced into the regions incorporated into the Soviet Union. Due to decisions taken by the Big Three (Churchill, Roosevelt, Stalin) for the purpose of discussing Europe's postwar organization during the Yalta Conference in February 1945, Poland fell into Soviet domination for almost 45 years. In 1944 the Polish state was reestablished within new frontiers (Poland lost its eastern lands for the benefit of Soviet Union and received territorial compensation in the West from Germany). The Big Three agreed to reorganize the communist Provisional Government of the Republic of Poland that had been installed by the Soviet Union. The first uniform accounting plan introduced in 1946 was inspired by the German model. 
The communists seized power immediately after the war. There followed a period of Stalinist repressions; from the late 50s on things were a little easier, though Poland continued to suffer from political oppression and economic hardship. In 1951-1953 the mixed model of economy was replaced by a centrally planned one Soviet system led to the introduction of the Soviet accounting plan. Reform of this system were undertaken in 1959, 1974 (influence of French uniform accounting system), and 1985. In 1957 the qualifications for the State Authorized Accountant were introduced to verify the accounts of state-owned enterprises. The stateauthorized accountants did not constitute independent profession. They were employed on a full-time basis and their role was to agree the appropriation of profits and verification of the achievements of centrally planned targets (Jaruga \& Schroeder 2003, pp. 25.02-25.03)

Polish accounting system came under the direct administration of Ministry of Finance. In place of general principles of accounting, derived from the commercial code and tax regulations, obligatory uniform measures for accounting were introduced by financial law. Accounting was reduced to record keeping and the emphasis was placed on the legal form. The financial statement were for such purposes as national statistics, measurement of achievements of centrally planned targets and price setting within the context of central economic planning (Jaruga \& Bailey 1998, pp. 15661567). The failure of centrally planned economy together with the activity of illegal opposition led to destruction of the monolith of communism. In the late 1980s and early 1990s the Communist Party was disbanded and democratic elections were held. It was the beginning of the process of transformation of the entire socioeconomic system. The objective was the creation of market economy and its integration into the wider global economy, with the prospect of admission to the market of European Communities. As a result commercial banks were created, stock exchange was reopened, the ownership of state enterprises was transferred, and economy was decontrolled.

Following the overthrow of Poland's communist regime in 1989 WSE was created as a joint-stock company on April 12, 1991. WSE held its first trading session on April 16, 1991 with five listed companies, all of which were formerly State-owned companies that had been privatized. In 1999, Poland reformed its pension system, which contributed to an increase in domestic institutional investment, and in 2004 it joined the EU. These developments helped to boost trading volume in subsequent years. WSE has become one of Europe's most dynamic IPO markets with 471 companies, including 51 foreign companies, listed on its main market (http://www.gpw.pl/historia_en).

Polish history shows that although WSE was founded in the same year as NYSE, it develops in fact for only 24 years and plays limited role in Polish economy. Bank credits are the main source of capital for Polish business units, including companies listed. The transformation is still in progress and investigation of EM in Poland is needed because the existing literature gives only limited view of this phenomenon. We have managed to identify only several papers, mainly theoretical, related to this problem. Review papers of Polish authors, for instance chapter of monograph by Grabiński et al. (2014), are prepared on the basis of foreign literature. Theoretical studies are, in chronological order (Prusak 2003 Wiatr 2008, Fladrowska \& Pawłowska-Tyszko 2010, Grabiński 2010, Kuzior 2011, Piosik 2011, Maruszewska 2011, StochniałekMulas \& Fita 2011, Bober 2012, Kuzior 2012, Burchart \& Lelusz 2014, Grabiński et al. 2014). Empirical studies are, again in chronological order (Jackowicz \& Kuryłek 2005, Wójtowicz 2005, Wójtowicz 2007a, Wójtowicz 2007b, Jackowicz \& Kozłowski 2010, Piosik \& Rówińska 2010, Wójtowicz 2010, Michalak et al. 2012, Wójtowicz 2012, Piosik et al. 2013).

An analysis of the scale of EM on Polish capital market leads to rough conclusion that managers of companies listed on WSE manage earnings in the extent similar to their counterparts from abroad. Wójtowicz (2010, p. 164-167) provided evidence on the basis of the research sample comprised 3325 observations (482 companies, years 1995-2007). Specifically, in cross-sectional distributions of earnings, unusually low frequencies of small losses were found, as well as unusually high frequencies of small positive income. EM to avoid losses is pervasive phenomenon, especially when environment conditions become difficult. The magnitude of this kind of EM was greater than in case of European countries being a basis for comparison. This result confirms theoretical conclusion that rules-based accounting system does not protect from EM. On the other hand income smoothing was much weaker than in the case of other countries. It was so perhaps because Polish managers first of all want to avoid losses, it is also possible that WSE is too young to enable gaining extra premium from the long string of growing values of yearly income.

Surprisingly, the use of IFRS in Poland, which formulate principles-based accounting system, at the very beginning caused growth of the level of earnings management. IFRS came into force due to administrative decision rooted in the process of European integration. It is assumed that the growth of magnitude of EM is caused by the natural reaction of the managers, willingly taking advantage of the wide range of freedom ensured by IFRS. The last result was obtained on the basis of relatively small sample (577 observations) comprising financial statements from the fiscal years 2005-2007 (Wójtowicz 2010, pp. 168-169).

Piosik et al. (2013) provided comprehensive analysis of EM in Poland using research sample comprised 1774 observations from consolidated financial statements of 120 companies from years 2000-2010. They conducted extensive analysis of the range, methods and possible reasons for EM. Earnings can be managed by depreciation and amortization of fixed and intangible assets ( $p$. 204) and write-downs of receivables and inventories and recognized provisions (pp. 208 and 214). Their results (summarized on pp. 195-200) suggest that in general the adoption of IFRS in Poland did not change the magnitude of EM in case of Polish companies.

Michalak et al. (2012) referred indirectly to EM because they focused on earnings quality. They tried to answer the question whether the mandatory implementation of IFRS increases earnings quality in Polish companies listed. They measured the following proxies of earnings quality: earnings persistence and accruals magnitude and looked into the height of special items. They provided evidence that mandatory IFRS implementation had a positive yet weak impact on the earnings quality of companies listed on the WSE

Jackowicz \& Kuryłek (2005) investigated EM to avoid losses in financial statement by Polish commercial banks. They manage earnings mainly by discretionary reserves to avoid reporting of small losses. Incentives to manage earnings are stronger in case of banks with equity to assets ratio lower than $12 \%$, smaller banks (size measured by the share in total assets of banking system) and during difficult crisis years. It seems that range of activity of the bank has no impact on EM

Jackowicz \& Kozłowski (2010) investigated the importance of profitability thresholds in case of commercial banks from Central Europe, including Poland, publicly and privately held. They observed discontinuities in profitability distributions around the relevant thresholds. The conclusion is that banks from Central European countries tried to avoid losses but they did not seem to care about profitability decreases.

The above review of Polish literature reveals that none of the authors dealt with the problem of EM to meet or beat analysts' forecasts. Heaving in mind the conclusion of Callao et al. (2014b) that the country of origin influences the perceptions and the results of EM investigations we have decided to begin research in this field. The hypothesis we put forward is that there exists EM to meet or beat analysts' forecasts in companies listed on WSE. This supposition together with the fact that Polish capital market can't be treated as matured as for instance American one and finally limited access to necessary empirical data are the premises to conduct a research for Polish companies. The problem of empirical data will be developed further in the next session. 


\section{Data}

In general there is no complete and comprehensive database containing actual and forecast values of earnings of Polish companies listed. We have asked for help professional analysts and stockbrokers from Polish brokerage houses. In day-to-day activity they use their own forecasts, data prepared by other professional and accessed by paid subscription to online content, for instance Bloomberg Professional Service. Furthermore, in practice not al companies listed on WSE are monitored by a certain number of professional analysts who publish their forecasts. Many of them are monitored by one or two professional teams or are not monitored at all.

To carry out the research we have decided to analyze companies included in the mWIG40 index as of end of May 2015. It excludes WIG20 (20 major and most liquid companies - blue chips) and sWIG80 (80 smaller companies listed) participants and foreign companies listed at WSE and other markets with the market capitalization at the ranking date above $€ 1$ billion. Since the analyzed period covers years 2012-2014 the structure of mWIG40 companies has been changing over time. The sample covers "JSW" which was on an element of WIG20 until end of December 2014 and "Cyfrowy Polsat", "Enea" and "Energa", which were included in mWIG40 until the same date but due to their rapid development jumped into WIG20. "Alchemia" was excluded from mWIG40 because of serious decline of its activity. We have not find any forecasts for "Stalprodukt", "Medicalgorithmics" and "Newag". We have manually collected earnings forecasts from web portals gathering wide range of financial data from various sources and from portal of one of Polish brokerage houses. Forecasts prepared by management of analyzed companies are excluded. Actual earnings are also manually collected from consolidated financial statements of companies, although they are available in many other websites and financial services.

Burgstahler \& Eames (2006) categorized forecasts into four forecast horizons depending on the number of days prior to the Wall Street Journal annual earnings release date, with the longest category 271 to 360 days. Since none of Polish financial journals or web portal plays the role similar to Wall Street Journal the analysis is conducted in relation to the end of fiscal year which in case of all companies is equal to the end of December. In practice in most cases financial statement of public companies are released in the first half of March of the year succeeding the fiscal year.

Consistent with Burgstahler \& Dichev (1997) and Burgstahler \& Eames (2006) to eliminate companies subject to more complex EM incentives associated with their regulatory environment, we excluded banks from the analysis. Since the data comprise a broad range of companies-sizes, we scale variable by beginning of-theyear value of total assets (total assets at the end of years 20112013, respectively).

Detailed investigation of the forecast horizon revealed that considerable number of forecasts was prepared in the fiscal years proceeding every single year covered by the analysis. For example 7 forecasts related to year 2013 were prepared in 2011 and 143 in 2012. All forecasts with so long horizon were rejected from the analysis. It is doubtful if managers and market participants are able to include such a long period in their decision process. Forecasts related to a given fiscal year released between its end and the publication of financial statement were considered. They are assumed to be especially valuable since they are published while financial statements are being prepared and hence managers have possibility to meet "the target" just above. For example out of 222 forecasts related to the year 2013180 were released in this year, 30 in January 2014 and 12 in February 2014 (the last one $18^{\text {th }}$ of February).

Total sample comprises 609 observations from 24 analysts related to 34 companies from years 2012-2014 (177 - year 2012; 222 $2013 ; 210-2014$ ). The average number of forecasts per company per year equals 5,97; minimum number of forecasts equals 0 ; maximum 19. The average number of forecasts per analyst per year equals 8,46; minimum 0 ; maximum 41 .

\section{Analysis and results}

Following Burgastehler \& Eames (2006) we analyze distribution of scaled forecast error called commonly in the literature earnings surprise, defined as:

Earnings Surprise $=($ Realized Earnings - Forecasted Earnings)/Beginning Total Assets

A significance level is set to $\alpha=0,05$.

As it was mentioned above observations were collected over three-year period of time, so formally we face the problem of panel data; on the other hand, referring to the goal of the research, we do not analyze variability of the phenomenon over time. Hence, single-factor ANOVA was used to check if cross-sectional study can be conducted. Panel a of Table 1 shows descriptive statistics for the earnings surprises in the entire sample and in every year. Outliers are removed from the analysis since they are assumed to be caused by errors in data. As outliers are treated earnings surprises lower than $1^{\text {st }}$ percentile $(-0,12788)$ and greater than $99^{\text {th }}$ percentile $(0,19322)$.

To check if the variances of earnings surprises in every year are statistically equal the Brown-Forsythe and the Levene's tests were used. P-values are, respectively, 0,0427 and 0,017; so that the null hypothesis of equal yearly variances should be rejected and hence formally $\mathrm{F}$ test related to means of earnings surprises should not be conducted. On the other hand on the basis of central limit theorem if the number of observation is large enough (in practice greater the 100) $\mathrm{F}$ test is robust to the violation of the underlying assumptions. The p-value for the $\mathrm{F}$ test related to equality of means of earnings surprises in every year is 0,032 so the null hypothesis is rejected. Firstly we used HSD Tukey test for unbalanced design to compare means between years. P-values are the following: 2012/2013 0,106; 2013/2014 0,928; 2012/2014 0,047. All these results are supported by Bonferoni's test: $\mathrm{p}=0,043$ for 2012/2014 but not by Scheffe's test: $p=0,0502$ (the differences 2012/2013 and 2013/2014 are not statistically significant). Note that p-values for Tukey's and Bonferoni's tests are "just below" the significance level. From these comparisons we determine that data provide statistical evidence to conclude that there are no differences between distributions of earnings surprises 2012/2013 and 2013/2014. There is only weak evidence that the year 2012 differs from 2014 and therefore cross-sectional study is conducted.

Table 1: Descriptive Statistics for Earnings Surprises

\begin{tabular}{|c|c|c|c|c|c|c|c|c|c|}
\hline & $\mathrm{N}$ & $1^{\text {st }} \mathrm{Q}$ & Median & $3^{\text {rd }} Q$ & Mean & Std. dev. & Skewness & Asym & Kurtosis \\
\hline \multicolumn{10}{|l|}{ Panel A } \\
\hline Total & 597 & $-0,017$ & 0,0001 & 0,009 & $-0,005$ & 0,036 & 0,107 & $-0,302$ & 6,648 \\
\hline 2012 & 175 & $-0,024$ & $-0,0028$ & 0,007 & $-0,011$ & 0,036 & $-0,745$ & $-0,354$ & 2,820 \\
\hline 2013 & 221 & $-0,016$ & 0,0000 & 0,009 & $-0,003$ & 0,027 & $-0,591$ & $-0,264$ & 1,964 \\
\hline 2014 & 201 & $-0,013$ & 0,0031 & 0,013 & $-0,002$ & 0,044 & 0,683 & $-0,227$ & 7,009 \\
\hline \multicolumn{10}{|l|}{ Panel B } \\
\hline Median of a year & 95 & $-0,017$ & 0,0015 & 0,010 & $-0,004$ & 0,035 & 1,128 & $-0,400$ & 13,006 \\
\hline Last forecast in a year & 95 & $-0,018$ & $-0,0008$ & 0,006 & $-0,005$ & 0,028 & 0,123 & $-0,426$ & 4,472 \\
\hline
\end{tabular}

Source: from author. 
To test the sensitivity of the results in relation to the choice of earnings surprise metric, we calculate results for the entire, basic sample and three subsamples (composite forecasts) - the median forecast in a given year, the last individual forecast in a given year (before the end of fiscal year), and the last individual forecast despite the date of its release. Panel B of Table 1 shows descriptive statistics for these earnings surprises and Fig. 1 shows distribution of earnings surprises in every subsample. ANOVA in every subsample shows that means of earnings surprises in every year are statistically equal ( $\mathrm{p}$-values in $\mathrm{F}$ test respectively 0,$658 ; 0,738$; $0,913)$; there are no statistical differences between variances (p-value in Brown-Forsythe and Levene's tests 0,286 or greater). The means of earnings surprises are negative (Table 1) so on average forecasted earnings are greater than realized, in other words, on average managers neither meet nor beat earnings forecasts. Two-tailed t-Student test for "Total sample" shows that this nega-

tive mean significantly differs for zero, $p=0,001$. The results are statistically but not content-wise different in case of three subsamples: "Median of a year" $\mathrm{p}=0,248$; "Last forecast in a year" $\mathrm{p}=0,110$; "Last forecast of all" $\mathrm{p}=0,305$.

The values of standard deviation for the entire sample and all subsamples are extremely high in relation to the means. Medians are not sensitive to outliers and especially in case of asymmetry of the distribution give better view of a central value. Median for the "Total sample" is 0, 0001 and means "just meeting" earnings forecasts. Median for subsample "Median of a year" equals to 0,0015 and for "Last forecast of all" equals 0, 0007. They both show beating of forecasts. In case of "Last forecast in a year" median is negative $-0,0008$. The reason for such a situation is yet unknown and requires further investigation.
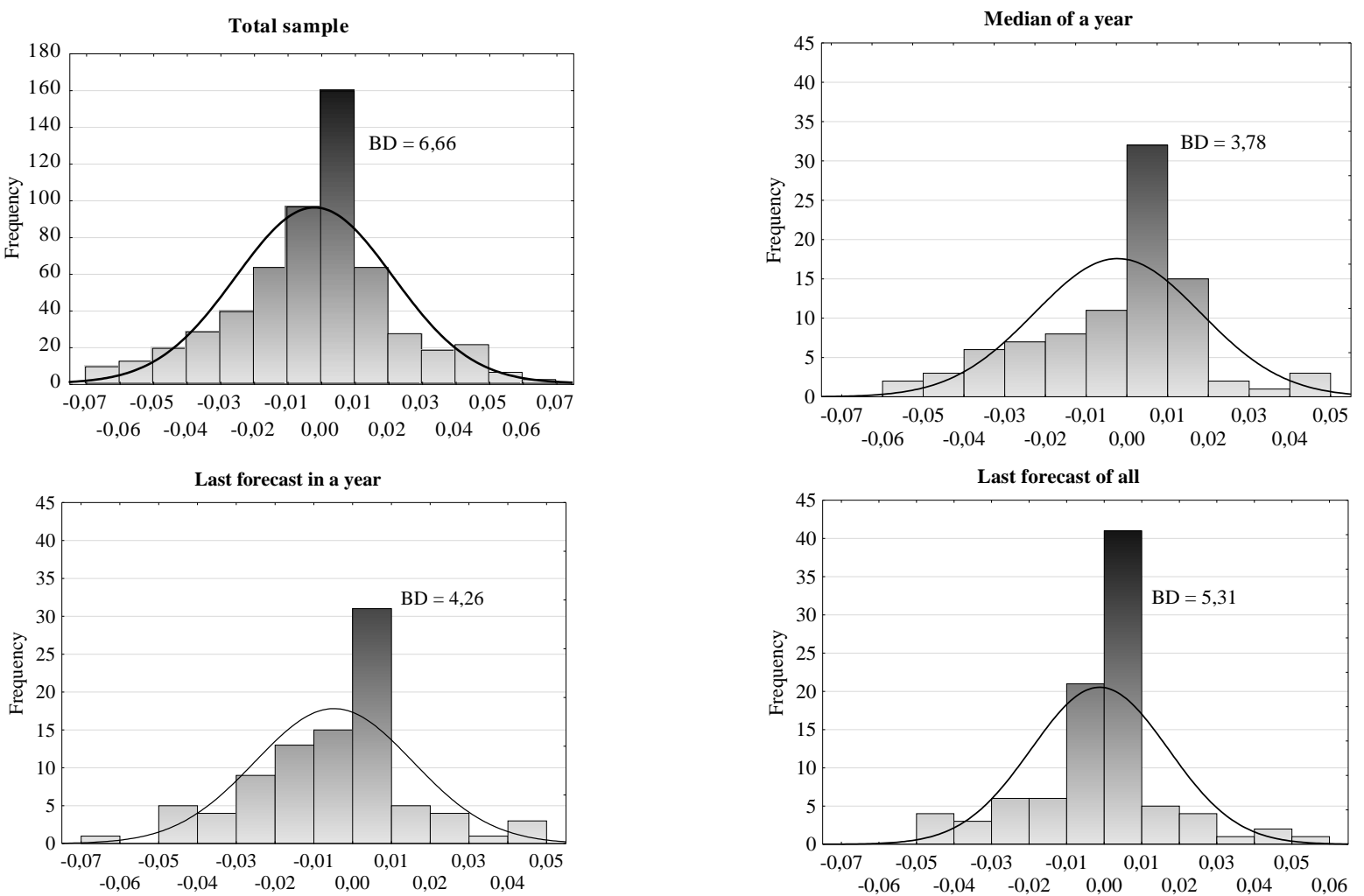

Fig. 1: Distribution of Earnings Surprises.

Source: from author.

Both Skewness and Asym measure asymmetry of the distribution. Skewness is defined as:

Skewness $=\mathrm{N} \times \mathrm{M}_{3} /\left[(\mathrm{N}-1) \times(\mathrm{N}-2) \times \mathrm{s}^{3}\right]$,

Where:

$\mathrm{M}_{3}=\mathrm{S}\left(\mathrm{x}_{\mathrm{i}}-\text { mean }\right)^{3}$,

$\mathrm{s}^{3}$ - standard deviation raised to power 3 .

In cases where one tail is long but the other tail is fat, Skewness does not obey a simple rule and hence quantile-based measure Asym is calculated:

\section{Asym $=\left(1^{\text {st }} \mathrm{Q}+3^{\text {rd }} \mathrm{Q}-2 \times\right.$ Median $) /\left(3^{\text {rd }} \mathrm{Q}-1^{\text {st }} \mathrm{Q}\right)$.}

Asym also measures direction and magnitude of asymmetry but only between first and third quartile and hence it is not sensitive to outliers. It is especially useful when calculation of mode and mean is difficult. Furthermore, EM of high magnitude is probably very costly or even impossible so looking for the symptoms of EM we should pay special attention to characteristics of the distribution close to its central value.

Positive Kurtosis in every subsample means that distribution is leptokurtic, i.e. has a sharper peak and fatter tails. Simultaneously, negative Asym, although moderate, shows that the tail on the left side of the distribution is fatter than the right side. Together it means that the probability of high negative earnings surprise is greater than in case of normal distribution. In other words, if module of earnings surprise is high it is more probable that the forecast of income is higher than the real value (neither meeting nor beating of the forecast). If the module of earnings surprise is small it is more probable that the real value is higher than the forecast (meeting or beating of the forecast), so small positive earnings surprises are more probable than negative. For example in case of "Last forecast of all" 41 out of 54 positive surprises are located in the range next to zero.

Fig. 1 is a histogram of the scaled forecast error variable with histogram interval widths of 0,01 for the entire range. The figure shows distribution with a single peak in the interval $[0 ; 0,01)$ in every subsample, i.e. earnings surprises slightly greater than zero occur more frequently than would be expected. To test the statistical significance of the hypothesized EM to meet or beat analysts' forecasts we use statistical test BD (Burgstahler \& Dichev 1997): 
$B D=\frac{n_{i}-\left(n_{i-1}+n_{i+1}\right) / 2}{\sqrt{N \times p_{i} \times\left(1-p_{i}\right)+\left[N \times\left(p_{i-1}+p_{i+1}\right) \times\left(1-p_{i-1}-p_{i+1}\right)\right] / 4}}$

Where:

$\mathrm{N}$ - Total number of observations,

$\mathrm{n}_{\mathrm{i}}-$ Number of observations in interval $\mathrm{i}$,

$\mathrm{p}_{\mathrm{i}}$-Probability that an observation will fall into interval $\mathrm{i}$, estimat-

ed by frequency.

Durtschi \& Easton (2005) and Durtschi \& Easton (2009) deny that any discontinuities in earnings distributions around zero can be attributed to earnings management, but Jorgensen et al. (2104) provide additional evidence consistent with unusual patterns in distributions arising from earnings management. The significance of the irregularity near zero is confirmed by the statistical test in every case. The BDs for the intervals immediately to the right of zero are presented at Fig. 1. Under the assumption that the standardized differences are approximately normal, the test statistics are significant at a level lower than $\alpha=0,05$.

\section{Summary}

Evidence in this paper supports assertions that managers of medium size companies listed at WSE take actions to avoid negative earnings surprises. Consistent with previous research it is shown that distribution of annual earnings surprises contains unusually high frequency of small positive surprises. If the module of earnings surprise is relatively high it is more probable that the forecast of income was higher than the real value - neither meeting nor beating the forecast. If the module of earnings surprise is small it is more probable that the real value was higher than the forecast meeting or beating the forecast. In short, small positive earnings surprises are more probable than negative. This result is confirmed by BD test statistics.

The above analysis asks also some questions but it is a first glimpse at the problem of EM to meet earnings forecasts in case of Poland. The results support the conjecture that managers take actions to upward manage earnings, and probably downward manage forecast, but this matter should be analyzed further with larger sample and more precise methods. The question arises if managers engage in "real" EM, reflected in cash from operations, or in actions of a "bookkeeping" nature, reflected in discretionary accruals, or maybe both, to achieve zero and positive earnings surprises. Means for avoiding a negative earnings surprise in case of Poland remains a topic for future research. The existence and kind of market responses to both types of earnings surprises in yet unknown.

\section{References}

[1] Arya A, Glover J \& Sunder S (1998) Earnings Management and the Revelation Principle. Review of Accounting Studies 3, Iss. 1, 7-34. http://dx.doi.org/10.1023/A:1009631714430.

[2] Arya A, Glover J \& Sunder S (2003) Are Unmanaged Earnings Always Better for Shareholders? Accounting Horizons 17, Supplement, 111-116. http://dx.doi.org/10.2308/acch.2003.17.s-1.111.

[3] Bartov E, Givoly D \& Hayn C (2002) the Rewards to Meeting or Beating Earnings Expectations. Journal of Accounting and Economics 33, Iss. 2, 173-204. http://dx.doi.org/10.1016/S0165-4101(02)00045-9.

[4] Bober P (2012) Kreatywna księgowość a ocena kondycji finansowej przedsiębiorstwa. Acta Universitatis Lodziensis Folia Oeconomica 262, 93-102.

[5] Burchart R \& Lelusz H (2014) Problemy w identyfikowaniu rachunkowości kreatywnej i rachunkowości agresywnej w teorii i praktyce. Zeszyty Teoretyczne Rachunkowości 77 (133), 51-64.

[6] Burgstahler DC \& Dichev I (1997) Earnings Management to Avoid Earnings Decreases and Losses. Journal of Accounting and Economics 24, Iss. 1, 99-126. http://dx.doi.org/10.1016/S0165 4101(97)00017-7.

[7] Burgstahler DC \& Eames MJ (2003) Earnings Management to Avoid Losses and Earnings Decreases: Are Analysts Fooled? Contemporary Accounting Research 20, Iss. 2, 253-294. http://dx.doi.org/10.1506/BXXP-RGTD-H0PM-9XAL.
[8] Burgstahler DC \& Eames MJ (2006) Management of Earnings and Analysts' Forecasts to Achieve Zero and Small Positive Earnings Surprises. Journal of Business Finance \& Accounting 33, Iss. 5-6, 633652. http://dx.doi.org/10.1111/j.1468-5957.2006.00630.x.

[9] Burgstahler DC, Hail L \& Leuz Ch (2006) The Importance of Reporting Incentives: Earnings Management in European Private and Public Firms. The Accounting Review 81, Iss. 5, 983-1016. http://dx.doi.org/10.2308/accr.2006.81.5.983.

[10]Callao S, Jarne J \& Wróblewski D (2014a) Debates and Studies on Earnings Management: a Geographical Perspective. Zeszyty Teoretyczne Rachunkowości 75 (131), 145-169, http://dx.doi.org/10.5604/16414381.1098803.

[11]Callao S, Jarne J \& Wróblewski D (2014b) the Development of Earnings Management Research. A Review of Literature from Three Different Perspectives. Zeszyty Teoretyczne Rachunkowości 79 (135), 135-177, http://dx.doi.org/10.5604/16414381.1133395.

[12]Degeorge F, Patel J \& Zeckhauser R (1999) Earnings Manipulation to Exceed Thresholds. Journal of Business 72, 1-33. http://dx.doi.org/10.1086/209601.

[13] Durtschi C \& Easton P (2005) Earnings Management? The Shapes of the Frequency Distributions of Earnings Metrics Are Not Evidence Ipso Facto. Journal of Accounting Research 43, Iss. 4, 557-592, http://dx.doi.org/10.1111/j.1475-679X.2005.00182.x.

[14] Durtschi C \& Easton P (2009) Earnings Management? Erroneous Inferences Based on Earnings Frequency Distributions. Journal of Accounting Research 47, Iss. 5, 1249-1281, http://dx.doi.org/10.1111/j.1475-679X.2009.00347.x

[15]Flądrowska E \& Pawłowska-Tyszko J (2010) Wykorzystanie rachunkowości agresywnej przez menedżerów i jej konsekwencje dla wierzycieli na przykładzie spółki handlowej branży rolnej - analiza przypadku. Zeszyty Teoretyczne Rachunkowości 58 (114), 99-110.

[16]Frank MM \& Rego SO (2006) Do Managers Use the Valuation Allowance Account to Manage Earnings around Certain Earnings Targets? The Journal of the American Taxation Association 28, Iss. 1, 43 65. http://dx.doi.org/10.2308/jata.2006.28.1.43.

[17]Grabiński K (2010) Zarządzanie zyskami jako jeden z kierunków rozwoju pozytywnej teorii rachunkowości. Zeszyty Teoretyczne Rachunkowości 56 (112), 71-82.

[18]Grabiński K, Kędzior M \& Krasodomska J (2014) Współczesna rachunkowość na rynkach kapitałowych. Difin, Warszawa.

[19]Graham JR, Harvey CR \& Rajgopal S (2005) the Economic Implications of Corporate Financial Reporting. Journal of Accounting and $\begin{array}{llll}\text { Economics } & 40, & \text { Iss. } & 1-3,73,\end{array}$ http://dx.doi.org/10.1016/j.jacceco.2005.01.002.

[20]Habib A \& Hansen J (2008) Target Shooting: Review of Earnings Management around Earnings Benchmarks. Journal of Accounting Literature 27, 25-70.

[21]http://finanse.wp.pl/gielda-prognozy.html?ticaid=114206. Accessed January 31,2015

[22] http://www.gpw.pl/historia_en. Accessed March 23, 2015.

[23] http://www.inwestinfo.pl/rekomendacje-i-prognozy/prognozy/. Accessed January 31, 2015.

[24]http://www.rynek.pekao.com.pl/news/narzedzia/prognozy. Accessed January 30, 2015.

[25]Jackowicz K \& Kozłowski L (2010) Zarządzanie wynikiem finansowym w bankach z Europy Środkowo-Wschodniej związane $z$ progowymi wartościami rentowności. Master of Business Administration 5 (114), 25-45.

[26]Jackowicz K \& Kuryłek W (2005) Unikanie raportowania strat przez banki komercyjne działające w Polsce. Studia i Prace Kolegium Zarządzania i Finansów Szkoły Głównej Handlowej 64, 63-84.

[27]Jaruga A \& Bailey D (1998) Poland. In European Accounting Guide (Alexander D \& Archer S eds.), Aspen Publishers, New York, 25.0125.36.

[28]Jaruga A \& Schroeder M (2003) Poland. In European Accounting Guide (Alexander D \& Archer S eds.), Harcourt Brace Professional Publishing, San Diego, New York, Chicago, London, 1564-1595.

[29]Jorgensen B, Lee YG \& Rock S (2014) The Shapes of Scaled Earnings Histograms Are Not Due to Scaling and Sample Selection: Evidence from Distributions of Reported Earnings per Share. Contemporary Accounting Research 31, Iss. 2, 498-521, http://dx.doi.org/10.1111/1911-3846.12020.

[30] Kasznik R \& McNichols M (2002) Does Meeting Earnings Expectations Matter? Evidence from Analyst Forecast Revisions and Share Prices. Journal of Accounting Research 40, Iss. 3, 727-759. http://dx.doi.org/10.1111/1475-679X.00069.

[31] Kinney W, Burgstahler D \& Martin R (2002) Earnings Surprise "Materiality" as Measured by Stock Returns. Journal of Accounting Research 40, Iss. 5, 1297-1329. http://dx.doi.org/10.1111/1475679X.t01-1-00055. 
[32]Kothari S (2001) Capital Markets Research in Accounting. Journal of Accounting and Economics 31, Iss. 1-3, 105-231. http://dx.doi.org/10.1016/s0165-4101(01)00030-1.

[33] Kuzior A (2011) Wycena operacyjnych aktywów trwałych a możliwości kształtowania zysków bilansowych w jednostkach stosujących MSSF. Zeszyty Naukowe Uniwersytetu Szczecińskiego 668, Finanse, Rynki Finansowe, Ubezpieczenia 41, 175-187.

[34]Kuzior A (2012) Zarządzanie zyskami bilansowymi przez wycenę wybranych elementów kapitału obrotowego. In Rachunkowość. Dylematy praktyki gospodarczej (Sojak S ed.), Wydawnictwo Naukowe UMK w Toruniu, Toruń, 337-352.

[35]Leuz C, Nanda D \& Wysocki P (2003) Earnings Management and Investor Protection: an International Comparison. Journal of Financial Economics 69, Iss. 3, 505-527.

[36]Lopez T \& Rees L (2002) The Effect of Beating and Missing Analysts' Forecasts in the Information Content of Unexpected Earnings. Journal of Accounting, Auditing \& Finance 17, Iss. 2, 155-184.

[37]Maruszewska E (2011) Polityka rachunkowości czy zarządzanie zyskami - artykuł dyskusyjny. Zeszyty Naukowe Uniwersytetu Szczecińskiego 668, Finanse, Rynki Finansowe, Ubezpieczenia 41 , 211-220.

[38] Michalak J, Waniak-Michalak H \& Czajor P (2012) Impact of Mandatory IFRS Implementation on Earnings Quality. Evidence from the Warsaw Stock Exchange. Zeszyty Teoretyczne Rachunkowości 68 (124), 63-82.

[39]Phillips J, Pincus M \& Rego SO (2003) Earnings Management: New Evidence Based on Deferred Tax Expense. The Accounting Review 78, Iss. 2, 491-521. http://dx.doi.org/10.2308/accr.2003.78.2.491.

[40]Phillips J, Pincus M, Rego SO \& Wan H (2004) Decomposing Changes in Deferred Tax Assets and Liabilities to Isolate Earnings Management Activities. The Journal of the American Taxation Association 26 , 43-66. http://dx.doi.org/10.2308/jata.2004.26.s-1.43.

[41]Piosik A (2011) Metodyka określania nieuznaniowych zmian rozliczeń międzyokresowych netto w analizie kształtowania wyników finansowych. In Rachunkowość a controlling (Nowak E \& Nieplowicz M eds.), Wydawnictwo Uniwersytetu Ekonomicznego we Wrocławiu, Wrocław, 479-492.

[42]Piosik A (ed.) (2013), Kształtowanie zysków podmiotów sprawozdawczych w Polsce. MSR/MSSF a ustawa o rachunkowości. C.H. Beck, Warszawa.

[43]Piosik A \& Rówińska M (2010) Determinanty dokonywania odpisów z tytułu utraty wartości aktywów trwałych na przykładzie spółek notowanych na GPW w Warszawie. Zeszyty Teoretyczne Rachunkowości 55 (111), 139-166.

[44]Prusak B (2003) Zniekształcenie rzeczywistej sytuacji finansowej przedsiębiorstw wskutek agresywnej ksiegowości. Prace Naukowe Katedry Ekonomii i Zarządzania Przedsiębiorstwem, Iss. 2, 151-160.

[45]Rees L \& Sivaramakrishnan K (2007) The Effect of Meeting or Beating Revenue Forecasts on the Association between Quarterly Returns and Earnings Forecast Errors. Contemporary Accounting Research 24 Iss. 1, 259-290. http://dx.doi.org/10.1506/G767-1674-5686-5375.

[46]Skinner DJ \& Sloan RG (2002) Earnings Surprises, Growth Expectations, and Stock Returns or Don't Let an Earnings Torpedo Sink Your Portfolio. Review of Accounting Studies 7, Iss. 2-3, 289-312. http://dx.doi.org/10.1023/A:1020294523516.

[47] Stochniałek-Mulas K \& Fita K (2011) Sprawozdania finansowe w krzywym zwierciadle. Zeszyty Teoretyczne Rachunkowości 64 (120), 129-140.

[48]Sunder S (2010) Adverse Effects of Accounting Uniformity on Practice, Education, and Research. Journal of Accounting and Public Poli$\begin{array}{llll}\text { cy } 29, & \text { Iss. } & 2, & 99-114\end{array}$ http://dx.doi.org/10.1016/i.jaccpubpol.2009.10.011.

[49]Wiatr M (2008) Bilans na miare XXI wieku - w kierunku sprawozdawczości kreatywnej czy doktryn bilansowych - artyku dyskusyjny. Zeszyty Teoretyczne Rachunkowości 42 (98), 369-382.

[50]Wójtowicz P (2005) O malowaniu zysków na polskim rynku kapitałowym. In Sprawozdawczość i rewizja finansowa w procesie poprawy bezpieczeństwa obrotu gospodarczego (Micherda B ed.), Centrum Rozwoju i Promocji Akademii Ekonomicznej w Krakowie, Kraków, 703-712.

[51]Wójtowicz P (2007a) Wpływ rewizji finansowej na kształtowanie zysków w celu unikania ujawniania strat. Zeszyty Teoretyczne Rachunkowości 36 (92), 130-146.

[52]Wójtowicz P (2007b) Kształtowanie zysków w celu unikania strat w spółkach niepublicznych. Zeszyty Teoretyczne Rachunkowości 38 (94), 249-264.

[53]Wójtowicz P (2010) Wiarygodność sprawozdań finansowych wobec aktywnego kształtowania wyniku finansowego. Wydawnictwo Uniwersytetu Ekonomicznego w Krakowie, Kraków.
[54]Wójtowicz P (2012) Próba identyfikacji czynników determinujacych kształtowanie wyniku finansowego w celu unikania małych strat $\mathrm{w}$ spółkach publicznych w Polsce. Zeszyty Teoretyczne Rachunkowości 65 (121), 111-130. 